\title{
Management Of Work Conflict, Work Stress In The Organization And How To Overcome Them
}

\author{
Meddiati Fajri Putri ${ }^{1}$, Moh. Muttaqin ${ }^{2}$ \\ \{media@mail.unnes.ac.id ${ }^{1}$, muttaqinm@mail.unnes.ac.id ${ }^{2}$ \} \\ Universitas Negeri Semarang, Sekaran Campus, Gunungpati, 502291,2
}

\begin{abstract}
Work conflict and work stress are unavoidable work problems. Both of these things often happen in an organization. Work conflicts can arise from yourself and the workplace environment. Meanwhile, from the work environment, for example, there is competition among coworkers, unable to meet the targets set by the company or organization. Broadly speaking, work conflicts are divided into two types, namely: Substantive conflicts, namely disputes related to group goals, allocation of resources within an organization and division of job positions and emotional conflicts that occur due to feelings of anger, distrust, unsympathetic feelings, fear and rejection, and the presence of interpersonal clashes (personality clashes). The consequences of work conflicts can be positive, it can be negative. As a result of increased work productivity because each individual tries to give his best, while the negative result of work conflict is that work stress will arise because each individual feels uncomfortable and each individual looks for the truth on his own.
\end{abstract}

Keywords: Management, work conflict, job stress.

\section{Introduction}

Many people hold the opinion that conflict is something negative and should be avoided, even though sometimes conflict is something that can make things better. Conflict can increase work motivation, improve product quality (because each will try to achieve the best), make competition healthy and so on. Besides having positive consequences, the negative consequences of conflict are job stress. There are organizations or companies that apply this conflict to achieve organizational or company goals, because they see conflict as very effective in improving performance. Several kinds of work conflicts, including conflicts that arise between individuals and groups or organizations and conflicts that occur within individuals themselves. What often happens is conflict between individuals and groups, because it involves a lot of other parties or work. This type of conflict will be very useful when the organization can manage it so that it can increase worker productivity. Emotional Conflict is more individual because it involves the feelings of each individual in doing his job and each individual will be different from one another.

Work conflict and work stress are two interrelated variables, because work conflict will cause someone to experience work stress if they cannot manage conflicts that occur in their work environment. Job stress can occur anywhere, not only in large companies. Usually work stress occurs because someone is being chased to achieve certain targets. 


\section{Work conflict}

The main text should be written using Times New Roman, 10pt, fully justified. Italics can be used for emphasis and bold typeset should be avoided.

\subsection{Definition of Work Conflict}

Conflict is a conflict that occurs between what a person expects of himself, other people, the organization and what he expects. Every human being will always have a perception of inequality or different points of view on something, so that these differences can lead to conflict [1]. Furthermore, according to [2] provides a definition of conflict as a struggle between needs, desires, ideas, interests or conflicting parties, as a result of differences in goals (goals); value (values); mind (cognition); feeling (affect); and behavior (behavior).

In a large organization, of course there will be conflicts, this cannot be avoided. Conflict can make an organization stable and develop, but it can also put an organization or company out of business. This conflict will continue as long as each party is still searching for the truth of each, so that mutually beneficial resolution of both parties is needed. Stress is one of the main areas of concern today in any organization and can be considered as a result of the pressure of various problems faced by humans in the organization. So that stress is manifested when people are faced with so much stress that their normal behavior patterns are affected. In other words, stress generally occurs because of a tense condition that affects one's emotions, thoughts and physical conditions [3].

[4] states that work stress is a condition of tension that creates a physical and psychological imbalance that affects emotions, thought processes, and the condition of a worker towards their environment. The occurrence of work stress can be understood as a situation where a person faces a task or job that cannot or cannot be reached by his / her abilities, for example if someone's ability only reaches 5 (five) but faces a job that demands ability with the number 9 (nine), then it is very possible once a person will be exposed to work stress [5]. [6] states that work stress is a condition of tension that affects a person's thought processes, emotions, and psychological conditions, the result is that too much stress can threaten a person's ability to face the environment and will ultimately interfere with the implementation of his duties.

[7] outlines that work conflicts that occur are divided into two types, namely: Subtantive conflicts (conflict between individuals and groups). This type of conflict often occurs because it relates to individuals and groups or companies. Each of them has a stand that is considered correct. An example for this case is the conflict between the finance department and the sales department. The sales department tries to meet the target by trying to sell as many products as possible, so the production must be large. On the other hand, the finance department is making cost savings, thereby reducing the cost of certain raw materials that are deemed less important. This conflict can be resolved if each of them sits together to find a solution.

Emotional conflicts (conflict because in the individual itself). Occurs as a result of feelings of anger, distrust of other people / the environment, unsympathetic to someone, fear of unclear reasons and rejection of the environment because it is not in accordance with expectations, as well as interpersonal conflicts. This personal conflict is more individual in nature. An example for this case is the individual feeling displeased with the leader because according to the individual the leader does not always listen to his aspirations or input, there can also be discomfort that has been brought from home (usually occurs in women). 
Furthermore, [7] further explains in organizational life, opinions about conflict can be seen from three perspectives, including

Traditional view. In this view, conflict is something that is unwanted and dangerous for organizational life. For example, if there is a conflict between the leader and the worker, the leader tries to get rid of the worker because he thinks this worker will hinder or make him uncomfortable.

View of behavior. This view argues that conflict is an event or event that usually occurs in organizational life that can be beneficial (functional conflict) and can also be detrimental to the organization (dysfunctional conflict). This view emphasizes that conflict can have both positive and negative consequences. Examples for functional conflicts include conflicts that occur in each part of an organization, for example conflicts between production and financial View interactions. According to this view, conflict is an event that cannot be avoided and is indispensable for organizational leaders, conflict can increase morale because each will compete to achieve goals. Examples of conflicts that occur between trade unions and employers. The union wants to increase the UMR, while the employer will increase the UMR after workers show their work results or improve the quality of their work. Each has a goal, the entrepreneur has the goal of improving the quality of the product, while the labor union has the goal of increasing the UMR.

Based on the three views above, the leadership of the organization needs to analyze the real conflicts that occur in the organization and how conflict management has a positive effect on organizational progress. Conflict is inevitable, every organization must have experienced conflicts, it remains how to manage the conflict itself so that it becomes positive both for the organization and for the workers.

\subsection{Types of Work Conflict}

According to [7] there are five known types of conflict, namely: Conflict Within A Person (Intrapersonal)

A person can experience internal conflicts in himself because he feels uncertain about which one he should choose, do or because the demands of too many tasks. Intrapersonal conflict is a person's conflict with himself. Conflict occurs when a person has two desires that cannot be fulfilled at once. As it is known that in a person there are usually the following things:

A number of competing needs and roles. A variety of different ways in which these roles and needs are generated. There are many forms of obstacles that can occur between motivation and purpose. There are both positive and negative aspects that hinder the desired goals.An example of an intrapersonal conflict, for example, a lecturer who happens to be concurrently a teacher must choose one, to become a lecturer or a teacher even though he / she already has the teacher's functional allowance.

The things above in a person's adaptation process to their environment often lead to conflict. There are three types of intrapersonal conflict, namely:

Conflicting approaches. For example a person who is faced with two equally attractive choices, for example a person is offered two jobs that he both likes.

Conflict-avoidance approaches. For example, a person who is faced with the same two choices makes it difficult, for example someone has to make a choice of two jobs that have the 
same risk. Avoidance-avoidance conflict. For example, people who are faced with one thing that has both positive and negative values, for example, a worker who works for a company that has strict regulations (it is very difficult to ask for permission to not come to work) but gets large compensation.

\section{Interpersonal Conflict}

Interpersonal conflict is a conflict between a person and another because of a conflict of interest or desire. This often occurs between two people with different status, position, field of work. Each individual competition occurs because they have different interests.

Conflict between individuals and groups

This conflict involves individuals with groups. If there is an individual who cannot fulfill the group's wishes, he will be punished.

Conflict between groups within the same organization

This conflict is a type of conflict that often occurs in organizations. Conflict between lines and staff, workers and management workers are two areas of conflict between groups.

Conflict between organizations

An example is in the economic sector where Indonesia and China compete in batik products. This is a form of conflict. Based on experience, this conflict has resulted in the development of new products, new technology and new services, lower prices and more efficient use of resources, as each country tries to produce products with low prices and quality.

In order for stress to be managed and minimized, individual workers and management should know the factors that cause work stress in the organization.

According to [8], in the context of daily work, workers who experience stress are caused by factors, including: (1) Types of work such as monotonous tasks, less challenges, lack of variety, unpleasant tasks. (2) Workload and work speed such as too little time to do, work under time pressure, tight and inflexible work schedules, unpredictable working hours, poorly designed shift schedules. (3) Participation and control such as lack of participation in decision making, lack of control (eg, over work methods, working at high speed). (4) Career development, status and compensation such as job security, lack of promotion prospects, weak payment schemes, minimum payment amounts, unclear performance evaluation systems, interpersonal relationships. (5) Work relations such as bad relationships with co-workers, bullying, harassment and violence, there is no work procedure. (6) Organizational culture such as poor communication, bad leadership system, lack of clarity about organizational goals. (7) Personal problems such as conflicts over work and home demands, lack of support at work, lack of support for work at home problems.

The results of the study explain that all the causes of stress are negatively related to job performance and organizational performance [9]. This means that the higher the level of stress experienced by workers, the lower their performance will eventually affect the performance of their organization as a whole. In a study conducted by [10] at Islamic banks in Indonesia, it was found that job stress is a factor that has a significant effect on the performance produced by workers. 


\subsection{Factors - Factors Causing Occupational Conflict}

The factors that influence conflict can be grouped into two major groups, namely internal factors and external factors. [7] in terms of internal factors, several things can be mentioned: Organizational stability. Organizations that are already established are usually able to resolve any conflicts because they respect the differences that occur. These organizations are used to dealing with conflicts so they know and resolve them quickly.

Value system. The value system of an organization is a set of boundaries that include the basis for the purpose and way of interacting with an organization, whether something is good, bad, wrong or right. The value system formed by the organization can be in the form of the rules applied in the organization, the organizational culture that has been running for years, and the habits that have occurred during the organization's existence. If this value system is good then it should be continued, but there are times when the value system is not quite right but it is considered correct. This needs to be addressed.

Purpose. The goals of an organization can form the basis of the behavior of the organization and its members. From one organization to another, of course the objectives are different, there are non-profit organizations (foundations, orphanages) and profit organizations (companies).

\subsection{Forms of Conflict and Work Stress in Organizations}

It was further explained by [7] that there are three forms of conflict in organizations, including:

Hierarchical Conflict (Hierarchical Conflict), Namely conflicts that occur at the level of the organizational hierarchy, for example conflicts between leaders and department heads. Hierarchical conflicts occur because of differences in the interests of each individual, differences in perceptions and possibly different goals.

Functional Conflict (Functional Conflict), Namely conflicts that occur from various departmental functions in the organization. For example, a conflict between the production department and the financial department. This conflict occurs because of differences in the goals of each part of the organization.

Formal - Informal Conflict (Formal-Informal Conflict), Conflicts that occur, for example, norms in formal organizations are carried out in non-formal organizations

The research problems of this study can be formulated as follows:why can work conflicts and work stress occur in an organization or company? Is there any effect of the conflict on performance or productivity? Can conflict and work stress be avoided?

\section{Discussion}

Conflicts can happen to anyone, both individuals and groups, this needs to be realized that each individual is different and each has different interests and goals. Based on the theoretical basis that has been stated above, it can be concluded that the causes of the conflict are:

The uniqueness of the individual, each of which has differences that are not owned by other individuals.

The nature of individual egoism. This attitude is reflected when the individual does not appreciate input from other parties. For him his opinion was the most correct and considered the opinions of others to be wrong. Differences in goals, especially between personal goals and organizational goals. 
The situation that has been brought from the previous place. If the individual has experienced problems from home, it will directly affect him when he goes to the office / workplace. The economic condition of the family which is completely deprived. This will have an impact on work because the individual will definitely be affected, especially if the compensation is not sufficient to meet the needs of the family.

Conflict prevention and management measures in organizations that can be implemented by management, namely:

(1) Management implements predetermined policies without tolerance for actions that violate these rules.

(2) Ensure that the established policies do not contain discrimination.

(3) Ensure that managers set a professional example in preventing and managing conflicts.

(4) Educating all members of the organization in communicating especially on any problems that occur and implementing strategies to reduce stress among staff.

(5) Assisting workers with problems as soon as possible, especially during busy times and ensuring a comfortable and safe physical work environment. Furthermore, [11] explains that the initial management can take steps to help them through facilitating, reconciling, mediating and negotiating those who are in dispute.

How to manage and manage work stress strategies according to [12], making organizational strategies will be able to help in overcoming stress in the workplace. Organizational strategies that can be implemented can include:

Determination of health and welfare procedures for workers. This includes various forms of health surveillance, health promotion activities, counseling on health-related issues and provision of adequate welfare facilities etc. These standards encourage managers, workers, workers and their representatives to work together to identify potential causes of stress in the workplace and then take action to improve the situation.

Management style. Here regarding environmental care is very important, the application of a good communication system and openness to all problems faced by workers. Change management. Management must recognize that impending change of any kind, is one of the most significant causes of stress in the workplace. This is generally related to job insecurity, insecurity, threats of termination of employment, loss of promotion prospects and so on. To eliminate the potentially stressful effects of change, a high level of communication as to what happened must be maintained and any such change must be properly managed step by step. Training activities. Worker training activities must consider the potential stress in certain work activities. People must be trained to recognize the elements of stress in their work and the strategies available to deal with this stress. In addition, job design and work organization must be based on the principles of their competence and expertise.

Strategies to deal with stress can also be done from the individual's side, for example by keeping away from stressors, processing thoughts by changing perceptions of stress, eliminating stressors, controlling increased stress and asking for social support from people around them. In addition, it can also be done through self-discipline by making regular work plans, work targets or work programs that can be reached.

[13] states that stress in an organization does not always endanger organizational life, as long as the stress that appears will only be at a low or moderate level. There are several ways that 
can be done to manage conflict and work stress:Troubleshooting. In the face of conflict trying to resolve it. This method can be done with the help of friends or closest people. The sooner the conflict is resolved the better. How to deal with conflicts and deal with problems include immediately dealing with people who have problems with you, because letting problems drag on is not good and it is getting harder to solve them. Furthermore, speak well and be calm, remain neutral, respect opinions, invite peace and ask for help if needed.

Avoiding conflict. Usually it happens to people who really don't like noise or conflict. Every time there is a difference the individual will try to avoid in any way, even he is willing to give in to avoid conflict. Compromise. Compromise is a good solution in resolving conflicts, because each individual can accept the decisions that have been agreed upon. Not all conflicts can be resolved by compromise. Order from authority. This method may not be suitable for some people, because this method of settlement is based on orders from the leadership, which inevitably must be completed. Maybe this method can be said to be forced to be completed.

Change structural variables. Because this type of conflict involves individuals who are involved in a leadership, conflict can be resolved by changing the organizational structure. This type of change often occurs in a company or organization.

The effect of conflict on performance or productivity. The existence of conflict will certainly have an impact on individuals, the positive influence will certainly have an impact on increasing productivity or performance. Examples of conflicts that have a positive effect are: if in each part there is competition to show its quality, it can be declared that there is a conflict. Each division responded positively to this competition by competing to produce quality products. Thus, conflict affects the performance or productivity of workers.

There is a theory that someone who is under pressure will produce optimal performance, so it can be concluded that when a person experiences stress, he can produce optimal work. Conflict is unavoidable. Conflict can animate an organization and can bring about change in the organization. Changes that can result from a conflict are:

(1) The company can produce products at low prices and quality. If this happens continuously, then the Indonesian State will be able to compete in the era of globalization.

(2) Each individual learns to appreciate differences and not selfishness, practice resolving conflicts wisely, patiently and not emotionally.

(3) Trying to solve every problem by means of compromise, discussion and together, so that the decisions taken are mutually agreed.

Besides having a positive impact, it is also necessary to know the negative impacts caused by conflicts that occur including the emergence of work stress which can be in the form of disharmonious relationships, decreased productivity, job insecurity, waste of working time and resources, decreased morale, loss of commitment to work, increased resignation, moral injury, unwarranted absence, and legal effects [14]. So it can be summarized that the role of conflict to be positive or negative depends on how we manage and negotiate the challenges and obstacles faced, influence, strengthen, or make peace with the conflicts faced.

\section{Conclusion}

The more a company develops, the higher the performance demands or the performance target standards set by the company, this will lead employees to strive to achieve the performance targets set by the company. Workers will maximize their work, adapt to environmental 
changes that occur, so that this condition will be vulnerable to work conflicts and work pressures that can cause stress to their workers. Stress and conflict cannot be separated, because severe and prolonged conflict will trigger conflict within individuals and between individuals in the organization. Conflicts and stress that are not handled properly will have an impact on employee performance which will later affect the overall performance of the organization.

Research conducted by [14] on the hotel industry in China has proven that conflict in organizations and job stress affect employee performance. It was found that conflict and work stress have a negative effect on worker performance, meaning that the higher the workers experience work conflict and the higher the stress they feel, their performance will decrease significantly, and vice versa. Where the conflict and stress felt by workers also affect their productivity and comfort at work. In this study it is suggested to managers that workplace conflicts cannot be avoided, especially when conflicts involving task completion or conflicts over interactions with work teams. Managers or leaders should assist their team in diagnosing the types of conflicts that arise and teach team members how to manage those conflicts.

Knowing the causes or sources of stress and work conflict triggers needs to be studied by company leaders so that they can develop strategies in anticipating and managing these two problems in their organization. Professional organizations will certainly find a way for the problems that occur so that their workers can work optimally and be productive in achieving the stated organizational goals.

\section{Suggestion}

It is necessary to carry out activities or programs that are familial in nature to strengthen the relationship between fellow workers

Management of tasks and roles as well as a clear organizational structure so that there is clarity of work for each worker, and there is no overload or excessive pressure.

Creating a strategy that involves workers can cause workers to get jobs that are in accordance with their abilities and they work for the goals they want as well as good interpersonal relationships

\section{References}

[1] Suryani, Ni Kadek, and Gede Agus Dian Maha Yoga. Konflik dan stres kerja dalam organisasi. Widya Manajemen; 2019. 99-113.

[2] Sedarmayanti. Manajemen Sumber Daya Manusia, Reformasi Birokrasi dan Manajemen Pegawai Negeri Sipil. PT Bandung: Refika Aditama. 2009

[3] Siagian, Sondang P. Manajemen sumber daya manusia. 2011.

[4] Rivai, Veithzal. Manajemen Sumber Daya Manusia untuk perusahaan. Raja Grafindo Persada. Jakarta:. 2004

[5] Sasono, Eko. Mengelola stres kerja. Jurnal Fokus Ekonomi. 2004. 3(2): 305-320.

[6] Handoko, T. Hani, and Basu Swasta. Perilaku Konsumen. Yogyakarta: BPFE. 2008.

[7] Sinambela, Lijan Poltak. Profesionalisme dosen dan kualitas pendidikan tinggi. Jurnal Sosial dan Humaniora. 2017. 2(4): 579-596.

[8] Leka, Stavroula, et al. Work organisation and stress: systematic problem approaches for employers, managers and trade union representatives. 2003. World Health Organization. 
[9] Walumbwa, Fred O., et al. Retracted: Authentically leading groups: The mediating role of collective psychological capital and trust. Journal of organizational behavior. 2011. 32(1): 4-24.

[10] Muda, Iskandar, Ahmad Rafiki, and Martua Rezeki Harahap. Factors influencing employees' performance: a study on the Islamic Banks in Indonesia. International journal of business and social science. 2014. 5(2).

[11] Barrister Ebe. Workplace Conflicts in Business Environment: The Role of Alternative Dispute Resolution (ADR). European Journal of Business and Management. 2014. 8(2).

[12] Stranks, Jeremy. Stress at work. Routledge; 2005.

[13] Sutapa, Mada. Stres dan Konflik Dalam Organisasi. Jurnal Manajemen Pendidikan. 2007; 1(7): $71-$ 77.

[14] Angelina Muganza, Causes and Impacts of Conflict at Workplace, Public Services Commission, Republic of Rwanda. 2014: 1 - 113.

[15] Alice H. Y. Hon dan Wilco W. Chan. The Effects of Group Conflict and Work Stress on Employee Performance, Special Focus on Human Resources in China Cornell Hospitality Quarterly. 2013; 54 (2): $174-184$. 